\title{
Aspek Sosial Budaya dalam Penyelenggaraan Penyuluhan: Kasus Petani di Lahan Marjinal
}

\author{
Siti Amanah, ${ }^{1}$ Endang L. Hastuti, ${ }^{2}$ Edi Basuno ${ }^{2}$
}

\begin{abstract}
This article focuses on explanation about socio-cultural aspects on the implementation of agricultural extension on farmers living on marginal lands. The paper was based on the research conducted on two population of farmers, in Bogor and Pontianak. Survey methods was used to collect data from 140 farmers' respondents. Results research showed that farmers in marginal lands ran their business in small scale, the ownership of the lands was less than 0.5 hectares, farmers living condition were in low level soscio-economic condition. There were significant correlation between the dyamic of socio cultural condition, strength agricultural policy, extension workers competency, farmers business with the farmers competency in managing the lands for agricultural business. To promote better condition of farmers in marginal lands, agricultural extension institution should be strengthened and extension workers capacity needed to develop to facilitate the change in terms of increasing the productivity lands to improve farmers welfare and conserving the environment as well.
\end{abstract}

Keywords: socio-culture, marginal lands, agricultural extension.

\section{PENDAHULUAN \\ Latar Belakang}

Secara umum pemanfaatan lahan marjinal di Indonesia masih belum optimal. Hal ini tergambar dari luasan lahan terlantar yang tersebar di Sumatera Selatan dan Kalimantan Tengah berupa rawa, lahan kering di beberapa wilayah di Jawa, Nusa Tenggara Barat dan Nusa Tenggara Timur; dan rendahnya produktivitas tenaga kerja. Pasandaran et al. (1991) menyebutkan bahwa produktivitas yang rendah pada pemanfaatan lahan marjinal antara lain disebabkan oleh: (1) motivasi usahatani yang bersifat subsisten, (2) ketidaksesuaian antara ketersediaan modal dan tenaga kerja dengan luas garapan, serta (3) keterbatasan kapasitas dalam menghadapi risiko akibat ketidaktentuan iklim. Pertanian di lahan marjinal dalam arti luas terbukti dapat dilakukan sebagaimana keberhasilan yang dicapai oleh peternak sapi potong di Blora (Sinar Tani, Edisi 14-20 Juni 2006), pemanfaatan lahan asam untuk budidaya

\footnotetext{
${ }^{1}$ Dosen Dept. Sains Komunikasi dan Pengembangan Masyarakat, Fak. Ekologi Manusia, Institut Pertanian Bogor, Email: sitiamanahasli@yahoo.co.id

${ }^{2}$ Peneliti Pusat Analisis Sosial Ekonomi dan Kebijakan Pertanian Departemen Pertanian, Email: endang_1804@yahoo.com
} 
ikan patin di Jambi, dan di beberapa wilayah penanganan lahan marjinal secara tepat dapat meningkatkan pendapatan warga setempat.

Lahan marjinal diantaranya lahan kering, sawah tadah hujan, dan pasang surut dapat dikelola untuk usaha produktif (Swastika dkk, 2006). Lahan marjinal dapat berperan bagi pengembangan usaha pertanian sebagaimana tampak pada Tabel 1.

Tabel 1. Model Usahatani Rumahtangga di Tiga Agroekosistem

\begin{tabular}{|c|c|}
\hline Agroekosistem & Model usahatani \\
\hline $\begin{array}{l}\text { 1. Sawah tadah hujan } \\
\text { Jawa Barat }\end{array}$ & $\begin{array}{l}\text { Pola tanam : padi - padi - palawija/sayuran } \\
\text { Ternak : domba, ayam buras dan kambing } \\
\text { Perkebunan : kelapa dan coklat } \\
\text { Model usahatani : Parsial }\end{array}$ \\
\hline 2. Lahan kering Bali & $\begin{array}{l}\text { Pola tanam : padi - palawija/sayuran } \\
\text { Ternak : sapi, babi dan ayam buras } \\
\text { Perkebunan : kelapa dan coklat } \\
\text { Model usahatani : Terpadu }\end{array}$ \\
\hline $\begin{array}{l}\text { 3. Lahan pasang surut } \\
\text { Kalimantan Barat }\end{array}$ & $\begin{array}{l}\text { Pola tanam : padi - palawija/sayuran } \\
\text { Ternak : sapi dan ayam buras } \\
\text { Perkebunan : kelapa } \\
\text { Model usahatani: Parsial }\end{array}$ \\
\hline
\end{tabular}

Sumber : Swastika dkk, 2006

Pengembangan sumber daya manusia pertanian, khususnya petani yang menjalankan usaha di lahan marjinal mutlak diperlukan. Dalam konteks pembangunan pertanian berkelanjutan, peningkatan keberdayaan petani dapat dilaksanakan melalui pendekatan sistem dan usaha berbasis pertanian yang adaptif dengan kondisi agroekosistem lahan kering, berdaya daya saing, pengembangan usaha ekonomi rakyat yang berkelanjutan, serta dilaksanakan dalam kerangka otonomi untuk memperkuat perekonomian di daerah dan nasional. Dalam jangka panjang, pelaksanaan sistem penyuluhan pertanian di lahan marjinal memiliki posisi strategis baik secara ekonomi maupun sosial. Pembangunan pertanian menurut Renstra Program Pembangunan Pertanian (Deptan, 2005) diarahkan untuk menerapkan berbagai pola pemberdayaan masyarakat petani sebagai pelaku agribisnis, memfasilitasi terciptanya iklim yang kondusif bagi perkembangan kreatifitas dan kegiatan ekonomi masyarakat, menyediakan sarana dan prasarana fisik oleh pemerintah berfokus pada pemenuhan kebutuhan publik yang mendukung sektor pertanian serta lingkungan bisnis secara luas, dan memicu akselerasi pembangunan wilayah serta merangsang tumbuhnya investasi.

\section{Permasalahan}

Permasalahan yang dihadapi dalam pendayagunaan lahan marjinal dapat dilihat dari berbagai segi. Pemanfaatan lahan marjinal untuk pengusahaan tanaman pangan kurang ekonomis, mengingat kondisi lahan yang cenderung labil, kurang atau tidak memiliki sarana pengairan yang memadai kurang, kondisi kimia, serta kemiringan 
lahan yang relatif tinggi (Syafruddin, 1998). Hingga kini kapasitas petani akan tata kelola lahan marjinal secara berkelanjutan relatif terbatas, sehingga diperlukan sistem penyuluhan yang mumpuni untuk peningkatan mutu sumber daya lahan. Penyuluhan yang mengutamakan peran petani sebagai subyek lebih mampu memberdayakan petani dan keluarganya (Pretty, 1995; Ibrahim, 2002; Amanah, dkk. 2004, Amanah 2006).

Dikemukakan oleh Taryoto (1995), sebagian besar wilayah miskin berada pada zona agroekosistem lahan kering, tadah hujan, pantai dan lahan rawa yang tergolong marjinal. Karakteristik wilayah miskin adalah sebagai berikut: (1) penguasaan teknologi budidaya pertanian relatif terbatas; (2) kurang berfungsinya lembagalembaga penyedia sarana produksi; (3) ketiadaan atau kurang berfungsinya lembaga pemasaran, sehingga usaha pertanian lebih bersifat subsisten; serta (4) kualitas prasarana transportasi dan komunikasi rendah, berkaitan dengan rendahnya kepadatan penduduk, produktivitas kerja serta rendahnya marketable surplus hasil usahatani.

Di wilayah Kabupaten Bogor dan di Pontianak terdapat kawasan lahan marjinal. Di Kabupaten Bogor, lahan kering ditemui di Kecamatan Tenjo dan Babakan Madang. Di Kabupaten Pontianak, lahan gambut masih luas dan belum didayagunakan secara optimal untuk usaha ekonomi produktif. Lahan kering termasuk dalam kriteria lahan marjinal. Pengembangan wilayah pertanian di lahan kering untuk tanaman pangan (padi gogo, jagung, kedele, kacang tanah dan lainnya) dan tanaman perkebunan (kelapa sawit, kopi, kakao, karet dan lainnya) memiliki peluang yang sangat besar. Lahan kering di Kalimantan memiliki luas sekitar 36,54 juta hektar yang mempunyai relief dari datar hingga berbukit dan tersebar didaerah dataran rendah sekitar 29,79 juta hektar dan dataran tinggi sekitar 6,76 juta hektar (Hidayat et al., 2000; Kurnia et al., 2000). Dari 29,79 juta hektar lahan kering dataran rendah terdapat sekitar 22,32 juta hektar lahan kering potensial untuk pengembangan dan sekitar 17,90 juta hektar diantaranya masih belum dikembangkan. Dari sekitar 6,76 juta hektar lahan kering dataran tinggi terdapat 79 ribu hektar lahan kering potensial untuk pengembangan dan hanya sekitar 67 ribu hektar lahan potensial yang masih belum dikembangkan. Alternatif pengelolaan lahan untuk usaha pertanian senantiasa dikembangkan oleh pihak terkait, ini pun masih dihadapkan pada kendala status kepemilikan lahan dan pengorganisasian petani. Atas dasar itu, artikel ini membahas kondisi faktual komunitas petani di lahan marjinal, dan faktor-faktor yang berhubungan dengan keberhasilan penyuluhan, kasus komunitas petani di lahan marjinal.

\section{Tujuan}

Tujuan penulisan makalah ini adalah dideskripsikannya kondisi faktual komunitas petani; dan dianalisisnya faktor-faktor yang berkorelasi dengan keberhasilan penyuluhan pertanian di lahan marjinal. Makalah ini diharapkan dapat berkontribusi perumusan kebijakan dan strategi penyuluhan pertanian pada situasi lingkungan yang ekstrem. 


\section{KERANGKA KONSEPTUAL}

\section{Konsep Lahan Marjinal}

Lahan merupakan faktor utama dan penentu senantiasa diperlukan oleh manusia untuk beraktivitas, lahan juga bermakna ruang, tanpa adanya ruang, sulit untuk bergerak. Istilah lahan marjinal sudah sering terdengar, dan terdapat beberapa pengertian, yakni secara teknis sulit untuk diusahakan bagi aktivitas usaha manusia, terutama sektor primer.

Konsep lahan marjinal dalam penelitian ini dimaknai sebagai kondisi teknis lahan yang kurang bagus bagi aktivitas pertanian, dan secara sosial dan ekonomi, kondisi masyarakatnya kurang menguntungkan. Artinya, lahan memiliki keterbatasan secara biofisik dan sosioekonomi (www.fao.org., diakses 5 Juli 2007). Dikemukakan oleh FAO, bahwa ada empat tipe lahan yaitu subur, kritis, marjinal, dan terdegradasi. Lahan marjinal adalah lahan yang memiliki keterbatasan tertentu, dan untuk meningkatkan produktivitasnya perlu dilakukan secara hati-hati agar tidak menimbulkan kerusakan lebih parah. Lahan marjinal mempunyai kendala biofisik seperti kurang subur, draniase buruk, kebasaan, keasaman, kondisi iklim yang tidak menentu. Kendala sosio ekonomik dari lahan marjinal diantaranya adalah kesulitan pasar, kepemilikan lahan timpang, infrastruktur buruk, dan rasio output/input rendah (www.fao.org, diakses 5 Juli 2007). Peningkatan pendapatan petani di lahan marjinal memerlukan upaya serius, antara lain: (a) teknologi usahatani berbasis agroekosistem setempat, dan (b) meningkatkan produktivitas sumberdaya pertanian dengan tetap memperhatikan kelestarian lingkungan.

\section{Studi tentang Petani di Lahan Marjinal dan Penyuluhan}

Bowling dan Barbara (2002) mengemukakan bahwa program penyuluhan dapat membentuk perubahan perilaku melalui prinsip berbagi pengetahuan dan pengalaman dengan masyarakat. Bersama-sama masyarakat, dapat dilakukan berbagai kegiatan yang mengarah pada pembentukan perilaku masyarakat. Dalam perubahan perilaku, diperlukan fasilitator yang disebut dengan pengantar pembaharuan (agent of change), baik dari dalam maupun luar komunitas (Adi, 2002). Kompetensi pengantar pembaharuan dalam membantu masyarakat untuk berdaya sangat penting untuk dimiliki yakni sebagai motivator, fasilitator, partner, dan dinamisator.

Penelitian Collier dkk (1997) tentang pendekatan baru dalam pembangunan pedesaan di Jawa yang dilakukan di 35 di Jawa dari tahun 1969 sampai tahun 1993 mengungkap bahwa mayoritas keluarga pedesaan terutama yang tuna kisma (landless) terdorong untuk bekerja di luar desa dan kebanyakan ke bidang jasa. Kemiskinan dan semakin menurunnya pendapatan dari pengusahaan pertanian di lahan kering berkontribusi terhadap hal ini. Sehingga alternatif pegembangan pertanian perlu diarahkan untuk menarik kembali kaum mudanya agar kembali menggarap lahan dengan teknik yang tepat. Dikemukakan oleh Collier dkk (1997), bahwa orang desa dalam hal ini petani bukanlah orang yang terbelakang, akan tetapi karena minimnya perhatian atau program pendidikan pertanian yang tepat untuk diakses petani berdampak pada penanganan lahan secara tidak tepat. 
Pendekatan penyuluhan yang berfokus pada transfer teknologi terbukti hanya menimbulkan permasalahan pada petani (Röling, 1988; Pretty, 1995). Röling (Oakley, 1988) melaporkan hasil penelitian yang dilakukan oleh University of Wageningen The Netherlands pada beberapa Negara Afrika membuktikan bahwa penyuluhan hendaknya mencakup lima kegiatan prinsip agar mampu mengurangi kemiskinan yaitu layanan suplai input, layanan teknis, pendidikan, organisasi, dan penyadaran. Pada kenyataannya, layanan penyuluhan di negara-negara berkembang terlalu terpusat pada suplai input dan layanan teknis, sedangkan persoalan pendidikan, pengembangan organisasi, dan penyadaran terlupakan. Aspek sosioekonomi dan teknis lingkungan sangat berperan dalam pengambilan keputusan petani dalam kegiatan usahataninya. Atas dasar persoalan yang dihadapi petani di lahan marjinal, maka dikembangkanlah kerangka berpikir studi ini (Gambar 1).

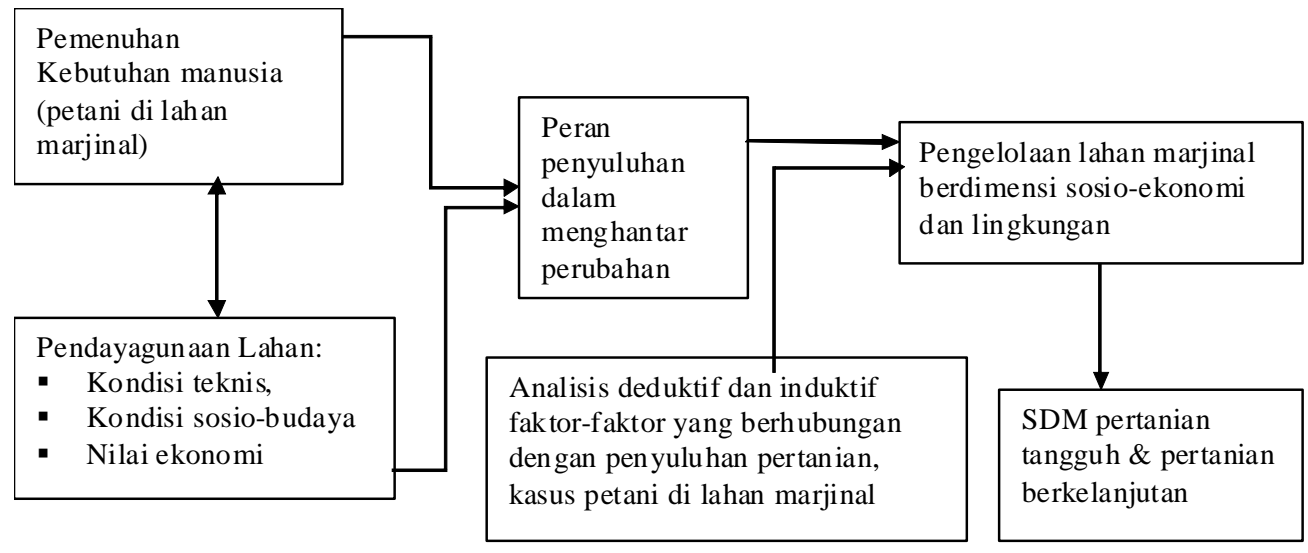

Gambar 1. Kerangka Pendekatan Studi

\section{METODE PENELITIAN}

Penelitian dilaksanakan di Kecamatan Tenjo dan Kecamatan Babakan Madang, Kabupaten Bogor, Provinsi Jawa Barat dan di Kecamatan Sungai Raya dan Kecamatan Rasau III Kabupaten Pontianak Provinsi, Kalimantan Barat. Penelitian dilaksanakan mulai Mei sampai dengan November 2007. Responden penelitian berjumlah 140 petani yang tersebar di empat kecamatan penelitian (Tabel 2).

Tabel 2. Sebaran Responden Petani di Lokasi Penelitian, Tahun 2007

\begin{tabular}{|l|l|l|l|l|l|}
\hline \multirow{2}{*}{ Lokasi Studi } & \multicolumn{2}{|l|}{ Kab. Bogor } & \multicolumn{2}{|l|}{ Kab. Pontianak } & Jumlah \\
\cline { 2 - 5 } & Tenjo & B. Madang & Rasau Jaya & Sei Raya & responden \\
\hline Responden & 30 & 41 & 51 & 18 & 140 \\
\hline
\end{tabular}

Data primer yang dikumpulkan meliputi karakteristik demografi petani, gambaran sosio budaya masyarakat, kebijakan, program dan aktivitas penyuluhan; kondisi lahan marjinal, perilaku usaha petani; dan kualitas hidup petani dan keluarganya. Data sekunder diperoleh melalui penelusuran informasi dari Penyuluh Pertanian Lapangan (PPL), Unit Pelaksana Teknis Dinas (UPTD) Lahan Kering, dan Badan Pengkajian dan Penerapan Teknologi Pertanian setempat. Data dianalisis secara 
deskriptif dan inferensial. Analisis data secara inferensial dilakukan dengan menggunakan uji $X^{2}$ dan korelasi rank-spearman untuk mengetahui keeratan hubungan antar peubah.

\section{HASIL DAN PEMBAHASAN}

\section{Gambaran Umum Petani dan Penyuluhan Pertanian di Lokasi Penelitian}

Sebagaimana umumnya kondisi masyarakat yang hidup dan berkembang di kawasan marjinal, maka pendidikan formal yang dicapai mayoritas Sekolah Dasar dan Menengah Pertama (Tabel 3). Keterjangkauan layanan pendidikan belum dapat dinikmati sepenuhnya oleh petani dan keluarganya. Sebagai alternatifnya, pendidikan non formal merupakan alternatif bagi pengembangan diri petani. Pelatihan yang dilaksanakan oleh Dinas Pertanian dan lembaga lain lebih banyak terlaksana di Kabupaten Bogor daripada di Kabupaten Pontianak (Tabel 4).

Tabel 3. Pendidikan Terakhir Responden di Lokasi Penelitian, 2007

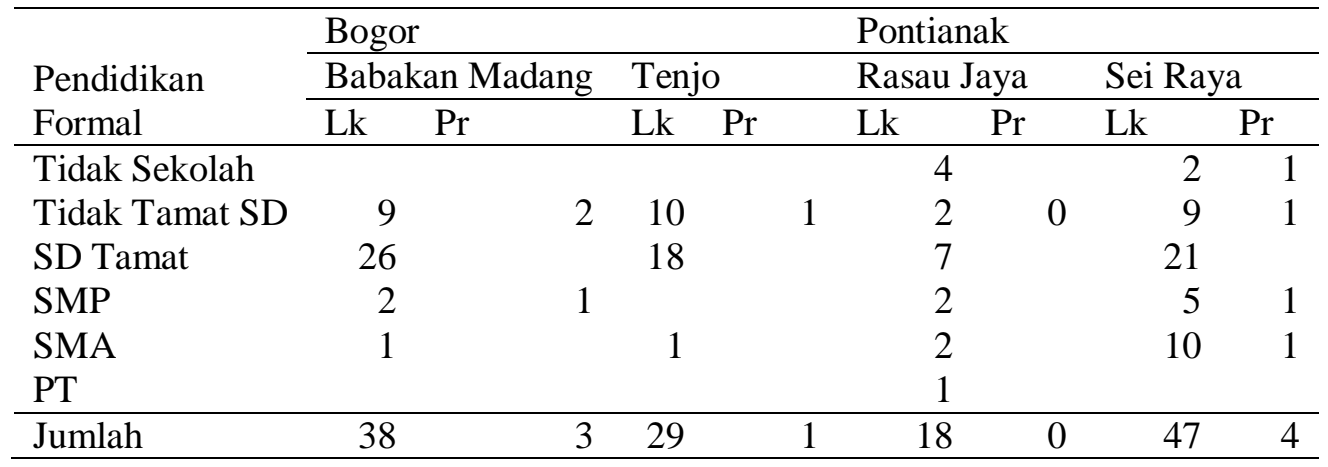

Keterangan: Diolah dari data primer; Lk =laki-laki; $\operatorname{Pr}=$ Perempuan

Tabel 4. Kesertaan Responden di Lokasi Penelitian dalam Pelatihan, Tahun 2007

\begin{tabular}{|c|c|c|c|c|c|c|c|c|c|}
\hline \multirow{3}{*}{$\begin{array}{l}\text { Pelatihan } \\
\text { Usahatani }\end{array}$} & \multicolumn{5}{|l|}{ Bogor } & \multicolumn{4}{|c|}{ Pontianak } \\
\hline & \multicolumn{2}{|c|}{ Babakan Madang } & \multicolumn{3}{|c|}{ Tenjo } & \multicolumn{2}{|c|}{ Rasau Jaya } & \multicolumn{2}{|c|}{ Sei Raya } \\
\hline & LK & $\operatorname{Pr}$ & LK & $\operatorname{Pr}$ & & LK & $\mathrm{Pr}$ & LK & $\operatorname{Pr}$ \\
\hline $\mathrm{Ya}$ & 23 & 2 & & 17 & & & & 12 & 2 \\
\hline Tidak & 15 & 1 & & 12 & 1 & & & 35 & 2 \\
\hline Total & 38 & 3 & & 29 & 1 & & & 47 & 4 \\
\hline
\end{tabular}

Keterangan: Diolah dari data primer; Lk =laki-laki; $\operatorname{Pr}=$ Perempuan

Kepemilikan lahan petani di Kabupaten Bogor sebagian besar merupakan lahan kering, sedangkan di Kabupaten Pontianak lahan garapan petani merupakan sawah tadah hujan (Tabel 5). Di dua wilayah kabupaten penelitian, selain jenis gambut, rataan luas lahan yang dimiliki masih di bawah 0,5 hektar. Lahan gambut yang dimiliki petani di Pontianak rata-rata berkisar antara 0,7 sampai dengan 1 hektar. 
Tabel 5. Rata-rata Kepemilikan lahan (Ha) di Empat Wilayah Penelitian, Tahun 2007

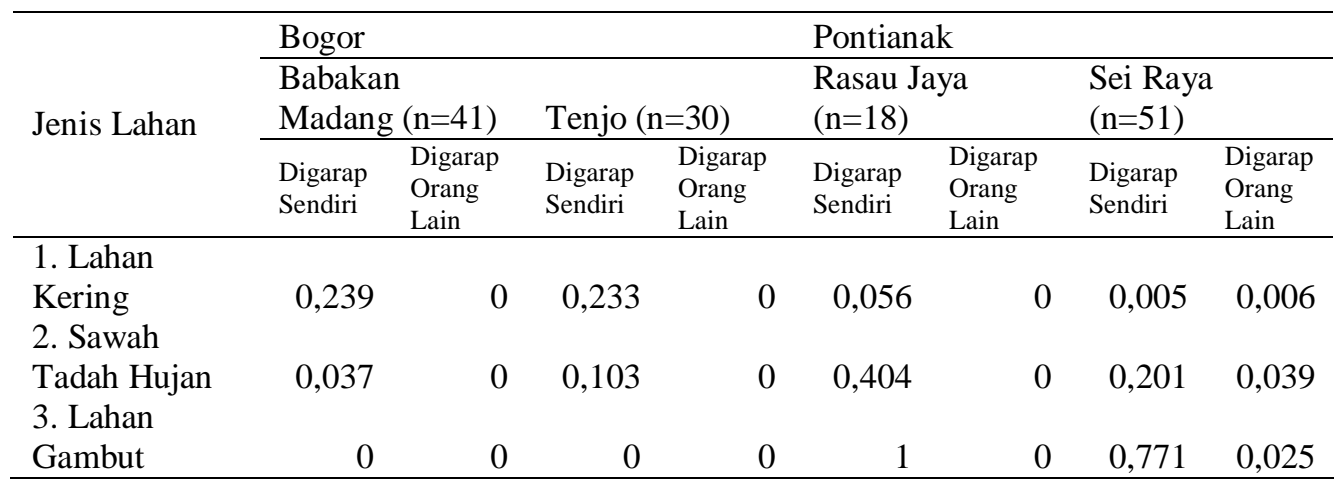

Keterangan: Diolah dari data primer

Selain mengelola lahan milik sendiri, petani di dua lokasi penelitian mengolah lahan milik orang lain juga dengan sistem bagi hasil. Luas lahan milik orang lain yang digrap umumnya kurang dari 1 hektar (Tabel 6)

Tabel 6. Rata-rata Luas Lahan Milik Orang Lain yang Dgarap Petani Responden di Empat Wilayah Penelitian, 2007

\begin{tabular}{|c|c|c|c|c|c|c|}
\hline \multirow[b]{2}{*}{ Jenis Lahan } & \multicolumn{4}{|l|}{ Bogor } & \multicolumn{2}{|l|}{ Pontianak } \\
\hline & $\begin{array}{l}\text { Babakan } \\
\text { Madang } \\
(\mathrm{n}=41)\end{array}$ & & $\begin{array}{l}\text { Tenjo } \\
(\mathrm{n}=30)\end{array}$ & & $\begin{array}{l}\text { Rasau Jaya } \\
(\mathrm{n}=18)\end{array}$ & $\begin{array}{l}\text { Sei } \\
\text { Raya } \\
(n=51)\end{array}$ \\
\hline 1. Lahan Kering & 0,721 & & 0,158 & & 0 & 0 \\
\hline 2. Sawah Tadah Hujan & 0,034 & & 0,087 & & 0,083 & 0,218 \\
\hline 3. Lahan Gambut & & 0 & & 0 & 0,139 & 0,054 \\
\hline
\end{tabular}

Keterangan: Diolah dari data primer

Rata-rata petani telah sepuluh tahun berusahatani dan bertani merupakan pilihan yang harus dilalui karena peluang lain terbatas (Tabel 7) Bertani dapat dilakukan meskipun petani tidak mempunyai lahan. Petani pun terdorong untuk mengembangkan kemampuan memanfaatkan lahan yang ada untuk usahatani mencukupi kebutuhan keluarga dan menambah penghasilan (Tabel 8).

Sebagian besar petani mengusahakan lahannya untuk tanaman padi gogo, palawija, dan usaha ternak. Permasalahan pertanian di lahan marjinal dapat dikategorikan menjadi permasalahan ekonomik, sosial, dan lingkungan. Dari sisi sosial, perkembangan terkini memperlihatkan adanya tiga hal penting yang mengemuka di masyarakat. Pertama, menurunnya daya dukung lingkungan; kedua, terdapat kecenderungan menurunnya nilai-nilai kebersamaan seperti suasana yang guyub, menurunnya aktivitas kegotongroyongan, dan kohesi sosial yang berkurang. Ketiga, dari sisi ekonomi, perkembangan sektor jasa semakin mendominasi aktivitas pertanian di lahan marjinal. Usaha pertanian terkendala oleh mahalnya harga sarana produksi, kurang terjaminnya harga jual komoditas, dan kegiatan penyuluhan terhenti oleh berbagai sebab yaitu, kurangnya sarana dan prasarana penyuluhan, 
kurangnya personil penyuluh, tiadanya lokasi demplot untuk percontohan dan penyelenggaraan pemerintahan di era otonomi daerah yang memandang penyuluhan sebagai aktivitas yang kurang strategis.

Tabel 7. Pengalaman Berusahatani Petani di Lokasi Penelitian, 2007

\begin{tabular}{|c|c|c|c|c|c|c|c|c|c|c|}
\hline \multirow{3}{*}{$\begin{array}{l}\text { Pengalaman } \\
\text { Usaha } \\
\text { (Thn) }\end{array}$} & \multicolumn{5}{|l|}{ Bogor } & \multicolumn{5}{|c|}{ Pontianak } \\
\hline & \multicolumn{2}{|c|}{ Babakan Madang } & \multicolumn{2}{|c|}{ Tenjo } & & \multicolumn{3}{|c|}{ Rasau Jaya } & \multicolumn{2}{|l|}{ Sei Raya } \\
\hline & Lk & $\operatorname{Pr}$ & Lk & $\operatorname{Pr}$ & & Lk & $\operatorname{Pr}$ & & Lk & $\operatorname{Pr}$ \\
\hline 0 & 2 & 1 & 3 & & & 1 & & & 3 & \\
\hline $1-10$ & 14 & 0 & 9 & & 0 & 6 & & 0 & 16 & \\
\hline $11-20$ & 10 & 1 & 8 & & 1 & 0 & & 0 & 7 & \\
\hline $21-30$ & 8 & 0 & 6 & & 0 & 6 & & 0 & 9 & , \\
\hline $31-40$ & 3 & 1 & 3 & & 0 & 4 & & 0 & 5 & \\
\hline$>40$ & 1 & & & & & 1 & & & 7 & 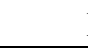 \\
\hline Total & 38 & 3 & 29 & & 1 & 18 & & 0 & 47 & 2 \\
\hline
\end{tabular}

Keterangan: Diolah dari data primer

Perbandingan Penyuluhan Pertanian di Kalimantan Barat dan Jawa Barat (Tabel 9) memperlihatkan bahwa terdapat indikasi lemahnya kelembagaan penyuluhan saat ini. Komitmen pemerintah daerah belum terlalu kuat dalam kebijakan dan strategi penyuluhan dalam memberdayakan petani.

Tabel 8. Alasan Responden menjadi Petani di Empat Wilayah Penelitian Tahun 2007

\begin{tabular}{|c|c|c|c|c|}
\hline \multirow[b]{2}{*}{ Alasan } & \multicolumn{2}{|l|}{ Bogor } & \multicolumn{2}{|l|}{ Kalimantan } \\
\hline & $\begin{array}{l}\text { Babakan } \\
\text { Madang }\end{array}$ & Tenjo & Rasau Jaya & Sei Raya \\
\hline 1. Tidak ada pilihan lain & 11 & 7 & 13 & 32 \\
\hline 2. Meneruskan orang tua & 6 & 12 & & 2 \\
\hline 3. Mengembangkan & & & & \\
\hline keterampilan usahatani di & & & & \\
\hline lahan marjinal & 14 & 2 & & 8 \\
\hline 4. Menambah penghasilan & 10 & 3 & 1 & 7 \\
\hline 5. Kombinasi 1 dan 2 & & 5 & 1 & 1 \\
\hline 6. Kombinasi 1 dan 3 & & & & 1 \\
\hline 7. kombinasi 1 dan 4 & & 1 & 1 & \\
\hline 8. Kombinasi 2 dan 4 & & & 1 & \\
\hline 9. Kombinasi 3 dan 4 & & & 1 & \\
\hline Jumlah & 41 & 30 & 18 & 51 \\
\hline
\end{tabular}


Tabel 9. Perbandingan permasalahan penyelenggaraan penyuluhan pertanian di dua lokasi studi, Tahun 2009

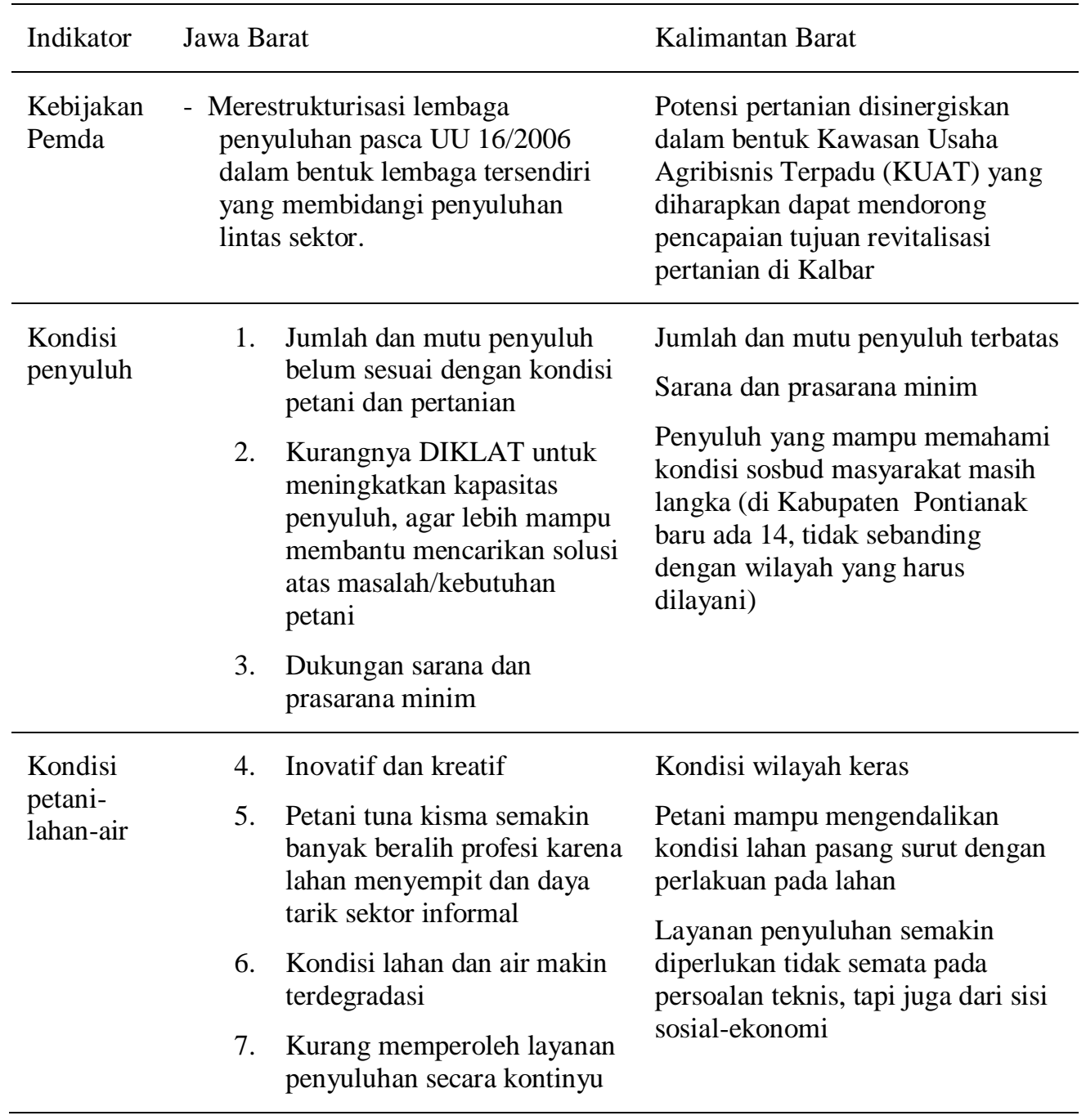

Keterangan: Analisis data primer

Peran penyuluh di masing-masing lokasi berbeda, di Jawa Barat peran penyuluh sudah dapat dilakukan oleh petani maju (kontak tani) sedangkan di Kalimantan Barat, peran PPL masih dominan, padahal jumlah PPL sendiri sangat terbatas. Hal ini berdampak pada kegiatan kelompok tani, di Jawa Barat kelompok tani berkembang secara lebih mandiri meski masih tetap memerlukan fasilitasi dari penyuluh. Di Kalimantan Barat, perkembangan kelompok tani tersendat dan sangat bergantung pada intervensi dari faktor luar. Hubungan antara penyuluh dengan petani dan kompetensi penyuluh sangat berhubungan dengan kelanjutan program dan hal ini pun perlu didukung oleh kebijakan penyuluhan di masing-masing lokasi. Perbedaan antar lokasi tampak nyata pada kemampuan penyuluh menggalang hubungan dengan petani. Pada penyuluh yang tekah berinteraksi intensif dengan masyarakat, maka tingkat kepercayaan petani tinggi, sehingga program akan lebih 
mudah dilaksanakan. Selain itu, komitmen pemerintah daerah akan penyuluhan sangat besar perannya bagi pencapaian tujuan penyuluhan. Penyuluhan sebagai investasi jangka panjang sangat diperlukan bagi percepatan transformasi perilaku petani dan keluarganya, oleh Mosher (1966) hal ini disebut sebagai syarat pelancar. Dalam kondisi keterpurukan sektor pertanian, maka penyuluhan perlu diperkuat sebagai tulang punggung kemajuan petani dan pertanian.

\section{Aspek Sosio Budaya dalam Penyelenggaraan Program Penyuluhan}

Aspek sosio budaya antar lain mencakup kaitan pasar dan orientasi ekonomi, jenis teknologi, mutu tenaga kerja, sumber energi yang digunakan, sumber modal, manajemen, spirit usaha yang menggerakkan, bentuk keorganisasian usaha, pelayanan usaha dan sebagainya. Dalam perspektif pembangunan berkelanjutan, sangat penting mengedepankan aspek partisipasi, keadilan sosial, pemeliharaan daya dukung ekosistem setempat (Pranaji dan Hastuti, 2004). Beberapa aspek sosial budaya yang berpengaruh terhadap program penyuluhan di lahan marjinal yang dibahas di sini meliputi, pengambilan keputusan dalam usahatani, aksesibillitas terhadap lembaga permodalan, kegotongroyongan, sikap berusahatani, penilaian terhadap aset, dan sikap terhadap penyuluhan.

\section{A. Pengambilan KeputusanUsahatani}

Di dalam pengelolaan ekonomi rumahtangga pengambilan keputusan dapat dilakukan oleh suami, istri, anak, atau keputusan yang diambil bersama oleh suami dan istri. Berbagai faktor berpengaruh terhadap kemampuan mengambil keputusan, antara lain potensi pribadi, pengalaman, lingkungan, dan sebagainya. Di lokasi penelitian di Kecamatan Tenjo, Babakan Madang dan Rasau Jaya, pengambilan keputusan dalam kegiatan usahatani sebagian besar diputuskan oleh suami, sedang di Sei Raya lebih banyak dimusyawarahkan oleh suami dan istri (Tabel 10).

Tabel 10. Persentase Responden Berdasarkan Pengambil Keputusan Usahatani, di Wilayah Penelitian di Jawa Barat dan Kalimantan Barat Tahun 2007

\begin{tabular}{lcrrr}
\hline $\begin{array}{l}\text { Pengambil } \\
\text { Keputusan }\end{array}$ & Jawa Barat & \multicolumn{2}{c}{ Kalimantan Barat } \\
\cline { 2 - 5 } Usahatani & Tenjo (\%) & $\begin{array}{l}\text { Babakan } \\
\text { Madang }(\%)\end{array}$ & $\begin{array}{l}\text { Sei Raya } \\
(\%)\end{array}$ & $\begin{array}{r}\text { Rasau } \\
\text { Jaya }(\%)\end{array}$ \\
\hline 1. Suami & 73 & 83 & 0 & 73 \\
2. Istri & 0 & 2 & 0 & 0 \\
3. Anak & 4 & 0 & 0 & 0 \\
4. Suami + Istri & 23 & 15 & 100 & 17 \\
\hline
\end{tabular}

Keterangan: Hasil analisis data primer

\section{B. Aksesibilitas terhadap Lembaga Permodalan}

Permodalan (Tabel 11) merupakan salah satu faktor penentu dalam kegiatan usahatani. Ternyata bahwa sebagian besar responden baik di Jawa Barat maupun Kalimantan Barat tidak akses terhadap sumber permodalan 
Tabel 11. Persentase Responden Berdasarkan Aksesibilitas Terhadap Lembaga permodalan di Wilayah Penelitian di Jawa Barat dan Kalimantan Barat Tahun 2007

\begin{tabular}{|c|c|c|c|c|}
\hline \multirow[b]{2}{*}{$\begin{array}{l}\text { Akses Terhadap } \\
\text { Modal }\end{array}$} & \multicolumn{2}{|l|}{ Jawa Barat } & \multicolumn{2}{|c|}{ Kalimantan Barat } \\
\hline & Tenjo (\%) & $\begin{array}{l}\text { Babakan } \\
\text { Madang (\%) }\end{array}$ & $\begin{array}{l}\text { Sei Raya } \\
(\%)\end{array}$ & $\begin{array}{r}\text { Rasau Jaya } \\
(\%)\end{array}$ \\
\hline 1. Tidak & 93 & 61 & 82 & 78 \\
\hline 2. Pernah & 7 & 39 & 18 & 22 \\
\hline
\end{tabular}

Keterangan: Hasil analisis data primer

Kelembagaan formal seperti bank atau lembaga pembiayaan yang lain relatif belum dapat melayani masyarakat di ke dua lokasi penelitian. Kios/ warung terdekat sangat besar peranannya dalam pelayanan untuk menyediakan biaya usaha tani. Pada umumnya petani setempat menukarkan hasil produksi dengan sarana produksi yang diperlukan, baik berupa pupuk maupun obat- obatan.

\section{Gotong Royong dalam Kegiatan Usahatani}

Di wilayah penelitian di Kalimantan Barat, aspek kegotongroyongan masih kental. Terlebih lebih di Rasau Jaya yang merupakan lokasi trans yang berasal dari Jawa, perasaan senasib merupakan modal sosial yang dapat menggerakkan masyarakat. Akan tetapi, penduduk yang berasal dari DKI kurang berhasil sebagai petani trans, dan banyak yang menjual lahannya kepada pendatang spontan, yang sebagian besar masih mempunyai hubungan kekeluargaan atau kedaerahan dengan petani trans sebelumnya.

Kegiatan disawah seperti tanam dan pemeliharaan masih sering dilakukan dengan cara giliran atau gotong royong untuk menghemat tenaga. Untuk ini pemilik lahan hanya menyediakan makanan. Masalah pertanian bukan hanya masalah laki- laki, namun juga masalah perempuan. Sehabis tanam padi, pada umumnya masalah pertanian menjadi masalah perempuan.. Meskipun demikian secara keseluruhan tidak semua responden melakukan kegiatan usahatani secara gotong royong. Responden di daerah penelitian di Kalimantan Barat dan Jawa Barat yang menyatakan masih melakukan kegiatan gotong royong usahatani seperti pada Tabel 12.

Tabel 12. Persentase Responden berdasarkan Pernyataan Adanya Kegiatan Gotong Royong dalam Kegiatan Usahatani, di Wilayah Penelitian di Jawa Barat dan Kalimantan Barat Tahun 2007

\begin{tabular}{lcllr}
\hline Kegiatan Gotong & \multicolumn{2}{c}{ Jawa Barat } & \multicolumn{2}{c}{ Kalimantan Barat } \\
\cline { 2 - 5 } $\begin{array}{l}\text { Royong Dalam } \\
\text { Kegiatan }\end{array}$ & $\begin{array}{r}\text { Tenjo } \\
(\%)\end{array}$ & $\begin{array}{l}\text { Babakan } \\
\text { Madang }(\%)\end{array}$ & $\begin{array}{l}\text { Sei Raya } \\
(\%)\end{array}$ & $\begin{array}{r}\text { Rasau Jaya } \\
\text { Usahatani }\end{array}$ \\
\hline 1. Ada & 96 & 100 & 96 & 100 \\
2. Tidak Ada & 4 & 0 & 4 & 0 \\
\hline
\end{tabular}

Keterangan: Hasil analisis data primer 


\section{Sikap terhadap Kegiatan Usahatani di Lahan Marjinal}

Di Kecamatan Sei Raya yang merupakan lokasi trans sepontan. Kondisi lingkungan sosial dan pertanian relatif sudah tertata dibandingkan Rasau Jaya. Sikap mental masyarakat untuk menata kehidupan pertanian relatif lebih positif. Meskipun demikian motivasi generasi muda untuk bekerja di sektor pertanian relatif menurun, yang disimbulkan dengan perkataan "sampun mboten jamane" mereka lebih tertarik pada pekerjaan di luar pertanian seperti berdgang, bekerja di pabrik atau sebagai pelayan toko.

Dahulu Desa Limbung merupakan desa yang subur dengan tanaman kopi, karet dan sebagainya. Dengan dibangunnya Bandara Supadio, saluran air terganggu karena banyak yang mampet, sehingga mengakibatkan banjir. Dalam satu tahu bisa 3 samapai empat kali banjir, dan pihak bandara tidak mau peduli. Padahal pada jaman Belanda pun, keberadaan saluran air ini sangat diperhatikan. Meskipun pernah mengusulkan kepada bupati setempat, namun belum ada perubahan. Lahan gambut terdapat di desa Sidomulyo, berjarak sekitar $3 \mathrm{Km}$ dari dusun tersebut, dan potensi sawah dapat mencapai sekitar 5-7 ton /ha. Masyarakat di desa- desa penelitian baik di Jawa barat maupun Kalimantan Barat, mengusahakan lahan marjinal karena berbagai alasan seperti pada Tabel 13.

Tabel 13 Persentase Responden Berdasarkan Alasan Menjadi Petani di Lahan Marjinal di Wilayah Penelitian di Jawa Barat dan Kalimantan Barat, Tahun 2007

\begin{tabular}{lcccc}
\hline $\begin{array}{l}\text { Alasan Menjadi Petani } \\
\text { di Lahan Marjinal }\end{array}$ & \multicolumn{2}{c}{ Jawa Barat } & \multicolumn{2}{c}{ Kalimantan Barat } \\
\cline { 2 - 5 } & $\begin{array}{l}\text { Tenjo } \\
(\%)\end{array}$ & $\begin{array}{l}\text { Babakan } \\
\text { Madang }(\%)\end{array}$ & $\begin{array}{l}\text { Sei Raya } \\
(\%)\end{array}$ & $\begin{array}{r}\text { Rasau } \\
\text { Jaya }(\%)\end{array}$ \\
\hline $\begin{array}{l}\text { 1. Tidak ada pilihan lain } \\
\text { 2. Meneruskan usaha orang }\end{array}$ & 56 & 83 & 86 & 78 \\
tua & 0 & 2 & 7 & 0 \\
$\begin{array}{l}\text { 3.Mengembangkan } \\
\quad \text { ketrampilan usaha tani }\end{array}$ & 6 & 0 & 0 & 0 \\
4. Lainnya & 16 & 14 & 5 & 21 \\
\hline
\end{tabular}

Keterangan: Hasil analisis data primer

Dari data-data pada Tabel 13, masyarakat tani mengusahakan lahan marjinal karena tidak adanya pilihan yang lain untuk berusaha, guna mencukupi kebutuhan ekonomi rumah tangga. Masyarakat tidak dapat merencanakan usahatani dengan baik, karena musim tidak dapat diperkirakan dengan baik. Kalau musim kemarau tanah pecahpecah, dan kalau musim hujan kebanjiran. Dengan adanya persahaaan kayu Sawmil sekitar tahun 60 an, banyak tanaman yang ditebangi, sehingga akhirnya habis. Dampaknya adalah penutupan perusahaan, sehingga terjadi PHK. Ke dua persoalan di atas mengakibatkan terjadinya degradasi ekonomi masyarakat tani. Pihak Bandara pun kurang memperhatikan masalah irigasi lahan petani, dan kurang melakukan perawatan terhadap parit- parit yang mengalami pendangkalan. Saluran Gertak Kuning dinilai kurang besar, sehingga tidak dapat menampung air hujan. Kebun atau lahan kering dapat ditanami pisang, jengkol, salak, kelapa, rambutan, jeruk, kopi, karet dan lainnya. Motivasi petani berdasarkan keinginan sendiri $(86,5 \%)$ 
cukup tinggi untuk mengolah lahan marginal. Hal ini antara lain disebabkan karena sudah tidak ada pilihan lain untuk mendapatkan penghasilan. Namun demikian untuk melakukan kegiatan usahatani sebagian besar masyarakat tidak mengetahui undang- undang budidaya tanaman

Ubi jalar ditanam di lahan-lahan yang relatif tinggi untuk mengatasi kebanjiran, dan dijadikan sebagai makanan selingan. Selain dari hasil sawah, petani juga mempunyai hasil kebun seperti kelapa, pisang, nenas, atau atau rambutan yang dapat dijual sedikit demi sedikit untuk mencukupi kebutuhan ekonomi rumahtangga. Sebagian besar responden mempunyai sikap bahwa lahan marjinal yang diusahakan bisa diperbaiki kesuburannya, seperti terlihat pada data Tabel 14.

Tabel 14. Persentase Responden Berdasarkan Sikap Terhadap Perbaikan Kesuburan Lahan Marjinal, di Wilayah Penelitian di Jawa Barat dan Kalimantan Barat Tahun 2007.

\begin{tabular}{llllr}
\hline Perbaikan Kesuburan & \multicolumn{2}{l}{ Jawa Barat } & \multicolumn{2}{l}{ Kalimantan Barat } \\
\cline { 2 - 5 } Marjinal & Tenjo & Babakan Madang & Sei Raya & $\begin{array}{r}\text { Rasau } \\
\text { Jaya (\%) }\end{array}$ \\
\hline Ya & $(\%)$ & $(\%)$ & 61 & 84 \\
Tidak & 80 & 100 & 39 & 16 \\
\hline
\end{tabular}

Keterangan: Hasil analisis data primer

Sikap masyarakat terhadap pemanfaatan lahan marginal relatif beragam, antara lain alam yang terdiri dari hutan, tanah, dan air diusahakan sebanyak mungkin untuk keperluan manusia, sebaiknya alam tidak dirusak atau alam tidak boleh dikelola sama sekali sesuai dengan apa adanya. Sikap-sikap tersebut sangat berpengaruh terhadap kegiatan usahatani dilokasi penelitian (Tabel 15).

Tabel 15. Persentase Responden Terhadap Sikap Pemanfaatan Alam, di Empaat Wilayah Penelitian di Jawa Barat dan Kalimantan Barat, 2007

\begin{tabular}{lcccc}
\hline Sikap Responden & \multicolumn{2}{c}{ Jawa Barat } & \multicolumn{2}{c}{ Kalimantan Barat } \\
\cline { 2 - 5 } Terhadap Pemanfaatan & $\begin{array}{l}\text { Tenjo } \\
(\%)\end{array}$ & $\begin{array}{l}\text { Babakan } \\
\text { Madang }(\%)\end{array}$ & $\begin{array}{l}\text { Sei Raya } \\
(\%)\end{array}$ & $\begin{array}{r}\text { Rasau } \\
\text { Jaya }(\%)\end{array}$ \\
\hline $\begin{array}{l}\text { 1. Diusahakan Sebanyak } \\
\text { Mungkin }\end{array}$ & 11 & 0 & 46 & 16 \\
2. Tidak Merusak alam & 83 & 100 & 54 & 84 \\
3. Tidak Boleh Dikelola & 6 & 0 & 0 & 0 \\
\hline
\end{tabular}

Sebagian besar masyarakat memilih untuk hidup serasi dengan alam, dengan tidak merusak alam untuk diusahakan dalam memenuhi kebutuhan manusia. Kegiatan rutin masyarakat umumnya adalah para suami hampir 50 persen bekerja pada kegiatan buruh bangunan, dengan upah Rp.30.000 per hari tergantung kesempatan. Wanita/gadis sebagai penjaga toko dengan penghasilan sekitar Rp.600.000 per bulan. Istri membuat makanan kecil seperti jagung yang digoreng mekar (marning) dan rangginang, dengan rata-rata penghasilan sekitar Rp.600.000 per bulan. Suami yang menjadi korban PHK karyawan bandara, sebagian besar beralih profesi sebagai petani dengan menyewa lahan milik bandara seharga Rp.5000/ anggar ( $18 \times 18 \mathrm{M}=$ 324M2). Selain sebagai buruh bangunan, usaha peternakan merupakan salah satu 
coping mechanism untuk mempertahankan ekonomi rumah tangga. Sekitar 80 persen penduduk Dusun Mulyorejo memelihara ternak sapi untuk menambah penghasilan rumahtangga. Kandang ternak pada umumnya didirikan di kebun, tidak menyatu dengan rumah.

Kegiatan kelompok tani relatif mengalami kemandegan, karena masih terbelenggu oleh program-program dari atas. Bahkan penyuluh yang dinilai paling berhasil, mengakui bahwa keberhasilannya hanya sekedar melaksanakan tugas dari atas. Kreatifitas di tingkat lokal yang sesuai dengan kebutuhan masyarakat masih relatif sedikit. Bentuk kegiatan yang dinilai paling cocok adalah sekolah lapang. Sikap masyarakat terhadap penyuluhpun negatif, karena penyuluh dianggap sebagai anak kecil, anak kemaren sore yang belum banyak pengalaman dalam berusaha tani.

Orientasi/perilaku petani sebagian besar masih bersifat subsisten, terlebih- lebih hasil dari lahan kering. Sebagian besar responden mempunyai sikap untuk melakukan upaya menyuburkan lahan marjinal (Tabel 17).

Tabel 17. Persentase Responden Berdasarkan Sikap Terhadap Perbaikan Kesuburan Lahan Marjinal, di desa-desa Penelitian di Jawa Barat dan Kalimantan Barat, Tahun 2007.

\begin{tabular}{|c|c|c|c|c|}
\hline \multirow{2}{*}{$\begin{array}{l}\text { Perbaikan } \\
\text { Kesuburan Lahan } \\
\text { Marjinal }\end{array}$} & \multicolumn{2}{|l|}{ Jawa Barat } & \multicolumn{2}{|c|}{ Kalimantan Barat } \\
\hline & Tenjo (\%) & $\begin{array}{l}\text { Babakan Madang } \\
(\%)\end{array}$ & $\begin{array}{l}\text { Sei Raya } \\
(\%)\end{array}$ & $\begin{array}{r}\text { Rasau } \\
\text { Jaya }(\%)\end{array}$ \\
\hline $\mathrm{Ya}$ & 80 & 100 & 61 & 84 \\
\hline Tidak & 20 & 0 & 39 & 16 \\
\hline
\end{tabular}

Ternyata masih cukup banyak responden yang melakukan upaya untuk memperbaiki lahan marjinal.. Meskipun jenis komoditas hortikultura seperti nanas, rambutan, mangga dan sebagainya cukup dapat tumbuh subur, namun hasilnya tidak dapat diserap pasar. Akhirnya hanya terbatas untuk mencukupi kebutuhan sendiri, atau dibagikan kepada tetangga. Di lokasi penelitian kelembagaan pembiayaan masih didominasi oleh warung- warung serba ada, yang berfungsi untuk menampung hasil pertanian yang ditukar dengan keperluan ekonomi rumah tangga. Selain itu juga menyediakan sarana produksi untuk berusaha tani seperti pupuk dan obat- obatan.

Empati, ternyata dapat mendorong individu untuk mengalami mobilitas vertikal. Seorang petani mampu mengelola lahan gambut dengan teknologi yang cukup tinggi, sehingga mampu menembus pasar ekspor. Lahan gambut bukan merupakan masalah, karena dapat dimanfaatkan secara optimal. Semenjak tahun 93 bertani di daerah ini, dan baru sekarang, tepatnya tahun 2006 mendapat jalan untuk memanfaatkan lahan secara optimal. Pada dasarnya untuk mengolah lahan di daerah ini harus secara corpored farming, yaitu kombinasi anatara peternakan dan pertanian.

\section{E. Sikap / Penilaian terhadap Aset}

Tidak semua masyarakat tani dapat hidup layak. Seperti dialami oleh responden yang lahir di Desa Rasao III Kecamatan Rasau Jaya. Sampai sekarang, petani tersebut belum mempunyai lahan, dan hanya menggarap lahan orang tua seluas 0,5 ha. Lahan ditanami padi, namun tahun lalu puso dan tidak menghasilkan. Kalau menghasilkan hanya sekitar $700 \mathrm{~kg}$ atau sekitar $1500 \mathrm{~kg} / \mathrm{ha}$. Anjuran PPL belum 
dapat dilaksanakan. Untuk mencukupi kebutuhan ekonomi rumah tangga, bekerja sebagai buruh tani dan buruh bangunan. Dalam satu tahun bekerja sebagai buruh non tani selama 5 bulan, yang dilakukan di luar desa dengan upah Rp.30.000 per hari. Di desa- desa penelitian baik di Jawa Barat maupun Kalimantan Barat, kekayaan, pendidikan, keturunan, dan status pekerjaan merupakan hal yang dinilai tinggi oleh masyarakat (Tabel 18).

Tabel 18. Persentase Responden Berdasarkan Penilaian Terhadap Aset yang Bernilai Tinggi, di Wilayah Penelitian di Jawa Barat dan Kalimantan Barat, 2007.

\begin{tabular}{lcccr}
\hline \multirow{2}{*}{$\begin{array}{l}\text { Jenis Aset } \\
\text { Pribadi }\end{array}$} & Jawa Barat & \multicolumn{2}{c}{ Kalimantan Barat } \\
\cline { 2 - 5 } & Tenjo (\%) & $\begin{array}{l}\text { Babakan Madang } \\
(\%)\end{array}$ & $\begin{array}{l}\text { Sei Raya } \\
(\%)\end{array}$ & $\begin{array}{r}\text { Rasau Jaya } \\
(\%)\end{array}$ \\
\hline 1. Kekayaan & 20 & 16 & 26 & 31 \\
2. Pendidikan & 43 & 50 & 36 & 7 \\
3. Keturunan & 20 & 20 & 12 & 7 \\
4.Status & 6 & 20 & 21 & 7 \\
Pekerjaan & 16 & 0 & 1 & 5 \\
5. Lainnya & & & & \\
\hline
\end{tabular}

Keterangan: Hasil analisis data primer

Masyarakat terdiferensiasi menjadi 3 golongan, yaitu golongan mampu, miskin, dan miskin sekali. Selain itu juga terdapat masyarakat yang bersahatani di lahan basah dan lahan kering. Diantara petani trans yang telah berusahatani di Rasau Jaya selama puluhan tahun, terdapat beberapa petani yang berhasil dan menyatakan keprihatinannya akan sikap masyarakat kepada penyuluh (Boks 1).

Masyarakat tani di wilayah Pak Toro bertugas semuanya adalah transmigran yang berasal dari daerah Jawa dan DKI. Menurut informasi transmigran yang berasal dari DKI banyak yang meninggalkan lokasi, dan lahan usahatani dijual kepada transmigran sprontan. Dari responden yang diwawancarai terdapat kasus transmigran sprontan yang berhasil, bahkan sekarang menguasai lahan sekitar 10 Ha..Saya kesini karena kemauan saya sendiri untuk mengubah nasib. Saya dituduh sebagai PKI, dan dicopot dari pekerjaan saya sebagai guru. Beruntung ada yang memberikan informasi mengenai lokasi ini, dan saya membeli lahan transmigran DKI, dengan cara menjual lahan saya di kampung. Alhamdullillah anak saya menjadi sarjana semua, dan istri saya sukses sebagai pengusaha marning dan rangginan. Saya berharap dapat naik haji dengan menjual sebagian lahan usahatani saya. Kasihan dengan Pak Toro, seringkali diremehkan orang dianggap tidak berpengalaman usahatani. Meskipun demikian saya tetap membantu di dalam pembentukan kelompok tani. Bahkan disini sudah ada Koperasi namanya "Kopentern atau Koparasi Pesantren. Saya sendiri memanfaatkan dana dari koperasi untuk beaya usahatani dan ekonomi rumahtangga.

Boks 1. Ungkapan akan sikap masyarakat terhadap penyuluh

\section{F. Sikap Terhadap Penyuluh dan Kegiatan Penyuluhan}

Dalam kaitannya dengan kegiatan penyuluhan dinilai belum berhasil. PPL dinilai kurang kreatif, karena hanya menjalankan perintah dari atas. Dari data-data yang diperoleh hanya 46,8 persen responden yang menyatakan pernah mengikuti kegiatan 
penyuluhan. Sedang dipelopori pembentukan Kelompok P4S (Program Pelatihan Petani Swadaya). Jumlah anggota kelompok terdiri dari 10 orang, yang bertujuan untuk mengubah struktur masyarakat. Kelompok ini diprakasai oleh guru dan petani maju di desa ini. Kalau kelompok P4S ini berhasil akan ditiru oleh masyarakat sekitar

Selama satu tahun yang lalu hanya terdapat satu program di Sei Raya yaitu SLPHT, yang diperkenalkan oleh Dinas Pertanian setempat. Dalam kegiatan ini dilakukan demplot dan penyuluhan secara khusus. PPL terlibat secara langsung di dalam kegiatan tesebut. Dengan cara demikian mendorong petani berusahatani lebih baik. Informasi yang nyata dan secara langsung dapat dengan cepat diserap dan diterapkan petani. Sedang program pemberian benih padi tidak berhasil karena masalah banjir.

Selama satu tahun yang lalu berbagai program dilakukan di Rasau Jaya antara lain jagung hibrida, biogas, usahatani terpadu (jagung dan ternak) Teknologi diperkenalkan oleh Peneliti BPTP dan Dinas Peternakan. Pertemuan kelompok dan di hamparan usahatani dilakukan satu kali per bulan. Untuk mendapatkan informasi diperoleh dari Liptan BPTP dan majalah Trubus. Sumber informasi yang terpenting diperoleh dari sesama PPL. Temu lapang dilakukan dengan distributor, setahun dua kali. Sekolah lapang (SL) merupakan salah satu strategi penyuluhan yang ampuh dan dalam banyak hal relatif lebih efektif dibanding dengan latihan dan kunjungan (LAKU). Pendekatan penyuluhan berkembang terus mengikuti perubahan zaman dengan berbagai indikasinya (Amanah, 2000:2) seperti perombakan struktur organisasi, strategi perencanaan, re-organisasi, pengkayaan teknik dan keterampilan penyuluh dan mendefinisi kembali prioritas baru.

\section{Analisis Hubungan antar Peubah dalam}

\section{Pengembangan Penyuluhan di Lahan Marjinal}

Analisis statistik dengan menggunakan $X^{2}$ (chi-square) menghasilkan bahwa ada tujuh dari 13 aspek yang diuji perbedaan keragaan penyelenggaraan penyuluhan dengan kondisi petani-penyuluh antar lokasi (Tabel 19).

Antara Jawa Barat dan Kalimantan Barat terdapat perbedaan dalam hal peran penyuluh, kegiatan kelompok tani, hubungan antara penyuluh dengan petani, kelanjutan program dan kompetensi penyuluh, dan kebijakan penyuluhan di masingmasing lokasi. Tidak terdapat perbedaan di dua lokasi studi dalam hal orientasi petani, kepemilikan aset, kegiatan kemasyarakatan, akses modal, produkstivitas usaha dan pengeluaran dala Peran penyuluh di masing-masing lokasi berbeda, di Jawa Barat peran penyuluh sudah dapat dilakukan oleh petani maju (kontak tani) sedangkan di Kalimantan Barat, peran PPL masih dominan, padahal jumlah PPL sendiri sangat terbatas. Hal ini berdampak pada kegiatan kelompok tani, di Jawa Barat kelompok tani berkembang secara lebih mandiri meski masih tetap memerlukan fasilitasi dari penyuluh. Di Kalimantan Barat, perkembangan kelompok tani tersendat dan sangat bergantung pada intervensi dari luar. 
Tabel 19. Hubungan antar Peubah Penyuluhan dan Pengelolaan Lahan Marjinal oleh Petani di Lokasi Penelitian, Tahun 2007

\begin{tabular}{llll}
\hline No Asosiasi hubungan peubah & $\begin{array}{l}\text { Nilai Pearson } \\
\text { Chi Square }\end{array}$ & P-Value \\
\hline 1 & Orientasi petani antar lokasi & 14.010 & 0,666 \\
2 & Kesenjangan kepemilikan aset antar lokasi & 16.270 & 0,061 \\
3 & Peran penyuluh di masing-masing lokasi & 55,281 (ada asosiasi) & 0,000 \\
4 & Kegiatan kelompok tani antar lokasi studi & 51.198 (ada asosiasi) & 0,000 \\
5 & Kegiatan kemasyarakatan antar lokasi & 42.619 & 0,176 \\
6 & Akses modal usahatani & 20.026 & 0,456 \\
7 & Hubungan penyuluh-petani & 48.094 (ada asosiasi) & 0,001 \\
8 & Kelanjutan program & 34.835 (ada asosiasi) & 0,000 \\
9 & Kompetensi penyuluh & 37.772 (ada asosiasi) & 0,001 \\
10 Kebijakan penyuluhan di masing-masing lokasi 10,613 (ada asosiasi) & 0,005 \\
11 Perilaku petani dengan sosbud yang berbeda & 100.991 (ada asosiasi) & 0,000 \\
12 & Produktivitas usaha antar lokasi & 15.469 & 0,217 \\
13 Pengeluaran dalam setahun & 136.999 & 0,460 \\
\hline
\end{tabular}

Sumber: Hasil anaisis data primer

Pengelolaan pertanian di lahan marjinal hanya akan berhasil dengan disusunnya perencanaan program yang matang. Perencanaan program penyuluhan akan berhasil mencapai tujuan, jika dalam pelaksanaannya berhasil melibatkan partisipasi segenap pihak terkait seperti pemuka masyarakat, petani, dukungan pemerintah lokal dan penyuluh sendiri. Hubungan antara penyuluh dengan petani dan kompetensi penyuluh sangat berhubungan dengan kelanjutan program dan hal ini pun perlu didukung oleh kebijakan penyuluhan di masing-masing lokasi.. Perbedaan antar lokasi tampak nyata pada kemampuan penyuluh menggalang hubungan dengan petani. Pada penyuluh yang tekah berinteraksi intensif dengan masyarakat, maka tingkat kepercayaan petani tinggi, sehingga program akan lebih mudah dilaksanakan. Selain itu, komitmen pemerintah daerah akan penyuluhan sangat besar perannya bagi pencapaian tujuan penyuluhan. Penyuluhan sebagai investasi jangka panjang sangat diperlukan bagi percepatan transformasi perilaku petani dan keluarganya, oleh Mosher (1966) hal ini disebut sebagai syarat pelancar. Dalam kondisi keterpurukan sektor pertanian, maka penyuluhan perlu diperkuat sebagai tulang punggung kemajuan petani dan pertanian.

Hasil uji korelasi rank-Spearman antara peubah-peubah penelitian dapat diperhatikan pada Gambar 3. Tampak bahwa kondisi sosio budaya, kompetensi penyuluh, kebijakan pemerintah,program penyuluhan, dan aktivitas usaha petani berhubungan positif nyata dengan perilaku petani dalam mengelola lahannya. Produktivitas pengelolaan lahan marjinal berkorelasi positif nyata dengan kesejahteraan petani. Hal ini berimplikasi bahwa semakin jelas dan terarah kebijakan dan program penyuluhan dan didukung kondisi sosio-ekonomi dan budaya yang kondusif akan mendorong petani bertindak positif terhadap lahannya melalui 
usaha agribisnis yang menguntungkan. Untuk mendampingi petani mengelola lahannya, diperlukan dampingan dari penyuluh yang kompeten.

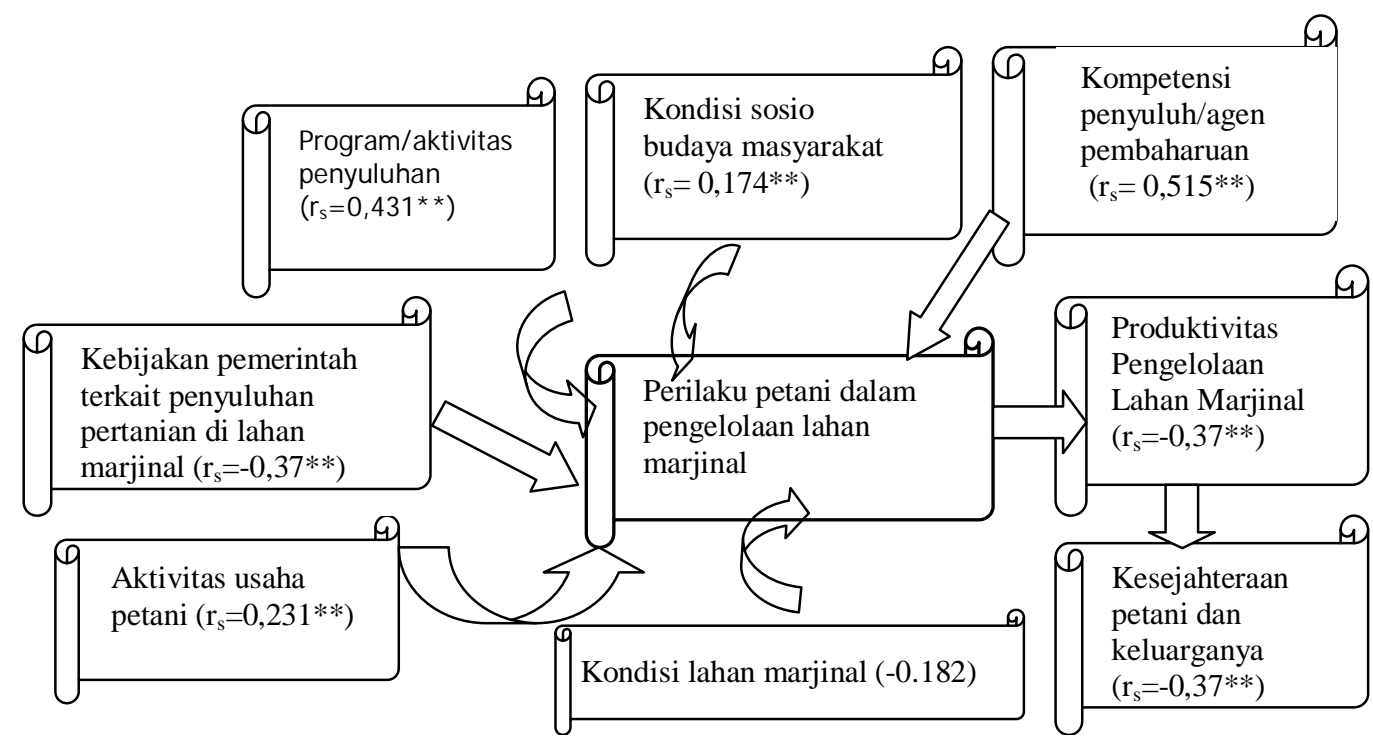

Gambar 2. Hubungan antar Peubah Penelitian

\section{KESIMPULAN}

Petani di dua lokasi penelitian dihadapkan pada kondisi lingkungan fisik yang semakin memburuk. Kelembagaan sosial pun mulai melemah perannya dalam pengembangan kapasitas petani mengelola usahatani di lahan marjinal. Petani lebih banyak peluang mengakses informasi, inovasi, dan teknologi pertanian. Peluang tersebut lebih banyak dinikmati oleh petani luas. Petani di Kalimantan Barat dihadapkan pada hasil panen produk lahan gambut yang belum sepenuhnya terserap pasar dan keterbatasan peluang kerja.

Kondisi sosio budaya, kompetensi penyuluh, kebijakan pemerintah,program penyuluhan, dan aktivitas usaha petani menentukan perilaku petani dalam mengelola lahannya. Produktivitas pengelolaan lahan marjinal kerkontribusi nyata kepada kesejahteraan petani.

\section{DAFTAR PUSTAKA}

Adi, Isbandi R. 2002. Pemikiran-pemikiran dalam Pembangunan Kesejahteraan Sosial. Lembaga Penerbit Fakultas Ekonomi Universitas Indonesia: Jakarta.

Amanah, S. 2000. New Approaches to Agricultural Extension. Dalam Prosiding: "The International Congress and Symposium on Southeast Asian Agricultural Sciences." CREATA-ICSSAAS: Bogor.

Fatchiya A., Syahidah D., 2004. Pemodelan Penyuluhan Perikanan pada Masyarakat Pesisir melalui Pendekatan Partisipatif. Laporan Penelitian Hibah Bersaing Perguruan Tinggi X (2002-2004). Institut Pertanian Bogor dan Proyek Pengkajian dan Penelitian Ilmu Pengetahuan dan Terapan, Direktorat Jenderal Pendidikan Tinggi, Departemen Pendidikan Nasional: Bogor. 
., 2006. Pengembangan Masyarakat Pesisir berdasarkan Kearifan Lokal di Kabupaten Buleleng, Provinsi Bali. Disertasi. IPB:Bogor.

Andrea Pisanelli, Chrisine H. Anyonge, R. Beck, Jurij Begus. 2006. Communication Strategies for multiple Partner Involvement in Forestry Extension Proceedings of the 7 th Extension Working Research Organization. IUFRO Working Party S6.06-03 Extension. Ovieto: Rome Italy.

Bowling, Chester J., dan Barbara A. Brahm. 2002. Shaping Communities through Extension Programs. Journal of Extension, June 2002 Volume 40 Number 3. http://www. joe.org/joe 2002june/a2.html.

Breman, J., dan Wiradi G., 2004. Masa Cerah dan Masa Suram di Pedesaan Jawa: Studi Kasus Dinamika Sosial-Ekonomi di Dua Desa Menjelang Akhir Abad Ke-20. Judul Asli: Good Times and Bad Times in Rural Java. Pustaka LP3ES Indonesia: Jakarta.

Brooks D. B., 2002. Case Study of Sustainable Improvement of Marginal Lands in Arsaal, Lebanon. IDRC Project No. 100855. Friends of the Earth: Canada.

Collier, W., Santoso K., Soentoro, Wibowo R., 1996. Pendekatan Baru dalam Pembangunan Pedesaan di Jawa: Kajian Pedesaan selama Dua Puluh Lima Tahun. Yayasan Obor Indonesia: Jakarta.

Departemen Pertanian, 2005. Renstra Badan Litbang Pertanian 2005-2009. Badan Litbang Deptan: Jakarta.

Hubeis, Aida V., Prabowo Tjitropranoto, dan Wahyudi Ruwiyanto. 1992. Penyuluhan Pembangunan di Indonesia Menyongsong Abad XXI. PT Pustaka Pembangunan Swadaya Nusantara: Jakarta.

Ibrahim, J. T. 2002. Kemandirian Petani dalam Pengambilan Keputusan: Kajian Reorientasi Penyuluhan Pertanian Ke arah Pemenuhan Kebutuhan Petani di Propinsi Jawa Timur. Disertasi. Institut Pertanian Bogor: Bogor.

Kasryno, F. (Penyunting). 1984. Prospek Pembangunan Ekonomi Pedesaan Indonesia. Yayasan Obor Indonesia: Jakarta.

Pasandaran E, Rusastra IW, Manurung VT. 1991. Perspektif Peningkatan Pendapatan Petani di Indonesia Bagian Timur. Forum Penelitian Agro Ekonomi (FAE) Vol. 9, No. 1, Juli 1991. Pusat Penelitian Sosial Ekonomi Pertanian: Bogor.

Pretty, Jules N. 1995. Regenerating Agriculture. Earthscan Publication: London.

Röling, N. 1988. Extension Science. Cambridge University Press: Cambridge.

Syafruddin, 1998. Upaya Peningkatan Produktivitas Lahan pada Sistem Usahatani Lahan Kering di Sulawesi Tengah. Makalah pada Seminar "Kinerja dan Adopsi Teknologi PPWT-SAADP" Bappeda Provinsi Sulawesi Tengah di Palu, 29 Nopember - 1 Desember 1998.

Sudarmanto, 1984. Dasar-dasar Penyuluhan Pertanian. Universitas Brawijaya: Malang. 
Taryoto, A. H. 1995. Kemiskinan dan Program Penanggulangan Kemiskinan Lingkup Departemen Pertanian : Suatu Upaya Introspeksi dalam Hermanto, $d k k$. (Eds). Prosiding Pengembangan Hasil Penelitian Kemiskinan di Pedesaaan : Masalah dan Alternatif Penanggulangannya. Buku 2. Pusat Penelitian Soial Ekonomi Pertanian: Bogor.

Pranaji.T.dan Hastuti Endang.L., 2004. Transformasi Sosio Budaya dalam Pembangunan Pedesaan. Analisis Kebijakan Pertanian. Volume 2 No.1.Pusat Penelitian dan Pengembangan Sosial Ekonomi Pertania. Badan Penelitian dan Pengembangan pertanian. Departemen Pertanian: Jakarta.

Koran:

Sinar Tani, Edisi 14-20 Juni 2006, Judul Artikel: “Blora Merupakan Sumber Sapi Potong bagi Jateng". 